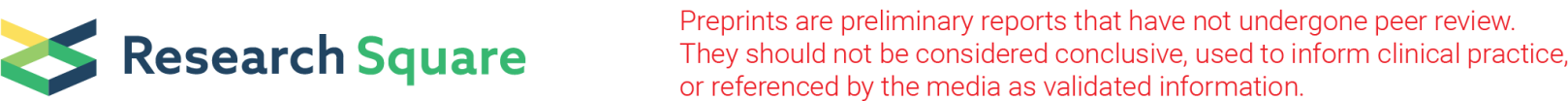

\section{A Method for Quantifying the Role of Carbonate Acid, Sulfuric Acid and Nitric Acid in Carbonate Weathering After Modifying the Effect of Evaporite in Qingjiang Karst Catchment}

Xinhui He ( $\nabla$ hexhcug@163.com )

China University of Geosciences School of Environmental Studies https://orcid.org/0000-0001-66168517

Hong Zhou

China University of Geosciences

Junwei Wan

China University of Geosciences School of Environmental Studies

Heng Zhao

China University of Geosciences School of Environmental Studies

Shiyi He

Institute of Karst Geology of Chinese Academy of Geology Sciences

\section{Research Article}

Keywords: Carbonate weathering, Inverse geochemical modeling, Gypsum, Karst groundwater

Posted Date: November 23rd, 2021

DOI: https://doi.org/10.21203/rs.3.rs-975403/v1

License: (c) (i) This work is licensed under a Creative Commons Attribution 4.0 International License.

Read Full License 


\section{Abstract}

Qingjiang river is the second largest tributary of the Yangtze River in Hubei province, it's also a typical karst catchment. Eighty-two important groundwater samples were collected during high and low water period of 2019. The results show that: (1) The major hydrochemistry types are $\mathrm{Ca}+\mathrm{Mg}-\mathrm{HCO}$ and $\mathrm{Ca}-$ $\mathrm{HCO}_{3}$, indicate that carbonate weathering is the main source of groundwater chemistry; (2) The results of inverse hydrochemical modeling show that there are two kinds of groundwater-carbonate rock interactions. One is co-dissolution of calcite and dolomite, the other is dedolomitization, and thereinto, dedolomitization is widespread in dolomite aquifers. Furthermore, gypsum has a tendency to dissolve in each aquifer, and the common ion effect of $\mathrm{Ca}^{2+}$ caused by gypsum dissolution promotes dedolomitization. The modeling results suggest that major elements have a good traceability effect on the material source of groundwater. (3) The chemical weathering of carbonate rock is mainly affected by carbonic acid, sulfuric acid and nitric acid. After modifying the impact of evaporite and atmospheric input, the calculations show that the contribution of carbonic acid involved in carbonate weathering is $70.9 \%$ (high water period) and $70.0 \%$ (low water period). Through statistics of karst springs discharge and contribution of acid involved in carbonate weathering, the two are in a positive relationship. The result can reflect the laws of sulfuric acid and nitric acid under the hydrodynamic condition in different seasons. Therefore, the carbonate weathering should be carefully evaluated in karst areas which have abundant groundwater and the role of groundwater in carbonate weathering is worthy of further study.

\section{Introduction}

Chemical weathering causes the transfer of chemical elements from rock to water, increasing solute of water (Zhang et al. 2016), at the same time chemical weathering consumes/releases $\mathrm{CO}_{2}$ to the atmosphere (Gaillardet et al. 1999; Moon et al. 2009). Therefore, carbonate weathering plays an important role in geological carbon sink, which affects global climate change (Gaillardet et al. 1999; Kump et al. 2000; Maher et al. 2014). Geological carbon sink mainly includes silicate weathering and carbonate weathering (Hartmann et al. 2009; Liu et al. 2011). The main reason

why carbonate weathering is neglected in global carbon cycle is its instability (Torres et al. 2014; Xie et al. 2021). Because carbonate weathering can quickly consume $\mathrm{CO}_{2}$ from the atmosphere, and it will release back to atmosphere through carbonate minerals precipitation, this process only lasts for centuries (Martin. 2017; Sun et al. 2021). However, dissolved inorganic carbon (DIC) converts into organic carbon by photosynthesis. This process can keep carbon remaining stable for a long time, thus making carbonate weathering become non-negligible carbon sink over geological timescale (Liu et al. 2011; Sun et al. 2021).

The intensity of chemical weathering depends on many factors, but a complex and changeable actual situation may lead to misestimate the influence of each factor (Moon et al. 2007; Yu et al. 2019). Lithology is an important factor that affecting chemical weathering, while different minerals have its own weathering resistance that determines the strength of chemical weathering. For example, the chemical 
weathering rate of carbonate rock is 12 times and 9.2 times faster than sandstone and granite, respectively (Meybeck. 1987). The chemical weathering rate of the river which flowing through steep terrain areas is significantly higher than other rivers (Zhang et al. 2016). Meanwhile, climate and topographic are usually positively correlated with weathering intensity (Zhang et al. 2019). Furthermore, aquatic organisms convert bicarbonate into organic carbon during non-flood season, this process contributes $15.5 \%$ of carbonate weathering (Sun et al. 2021), so this factor should be considered when estimating the carbon sink of carbonate weathering. While carbonate weathering by exogenous acid (mainly includes sulfuric acid and nitric acid) plays an important role in areas where human activities have a greater impact (Li et al. 2011; Yu et al. 2015). Because exogenous acid produced by human activities participates in carbonate weathering that will release $\mathrm{CO}_{2}$ to the atmosphere. Thus, calculating the contribution of sulfuric acid and nitric acid involved in carbonate weathering is an effective method to evaluate the weathering of exogenous acid (Li et al. 2011; Xie et al. 2021).

River solute derives from rock weathering, soil leaching and atmospheric input, and it is a comprehensive reflection of groundwater, rainwater, soil water and biological effects (Soulsby et al. 2007; Liu et al. 2021). There are many studies of chemical weathering intensity on catchment scale (Han et al. 2004; Wang et al. 2012; Sun et al. 2021). However, few people pay attention to carbonate weathering under the influence of evaporite mineral, such as gypsum. The Yangtze Platform was in a hot and dry climate when the karst aquifer was formed in Central China, seawater evaporated and crystallized into carbonate and evaporite minerals ( $\mathrm{Li}$ et al. 2020). Previous studies have shown that the existence of evaporite has different effects on the dissolution of carbonate mineral under different environmental conditions (Garcia-Rios et al. 2014; Yu et al. 2019). However, there are few studies on how evaporite mineral affect carbonate weathering in natural karst aquifer.

Qingjiang river is a typical karst catchment in the middle reaches of the Yangtze River, and it is also a National Key Ecological Function Zone (Sun et al. 2016; Jiang et al. 2017). The study area includes formations from Sinian to Triassic, which restricts carbonate rock and evaporite in the study of hydrogeochemical process. In this study, Qingjiang catchment is taken as an example to establish the hydrogeochemical background of each karst aquifer for reference. The contribution of carbon acid, sulfuric acid and nitric acid involved in carbonate weathering has been calculated after modifying by evaporite. This study expects to provide scientific basis for chemical weathering where evaporite existence.

The aims of this research are to: (1) establish the hydrogeochemical background of the karst aquifers distributed in the Yangtze Platform in Central China, (2) calculate transfer amount of mineral in karst aquifers, (3) discover the differences and mechanisms of hydrogeochemical processes in different hydroperiod, (4) estimate the contribution of carbon acid, sulfuric acid and nitric acid involved in carbonate weathering after modifying the influence of evaporite.

\section{Study Area}


Qingjiang river $\left(108^{\circ} 33^{\prime}-111^{\circ} 27^{\prime} \mathrm{N}, 2^{\circ} 23^{\prime}-30^{\circ} 52^{\prime} \mathrm{E}\right)$ is the second largest tributary of the Yangtze River in Hubei Province (Fig.1), with a total length of $423 \mathrm{~km}$, the total area of Qingjiang catchment is $16,700 \mathrm{~km}^{2}$, and average slope of the river is 3.07\%o (Du et al. 2012). The study area is located in the northeastern edge of Wuling Mountains, bordering on western Sichuan Basin and transitioning to eastern Jianghan Plain. while the elevation is higher in the west and lower in the east. According to the topographical features, Qingjiang river is divided into three sections: the west of Enshi is upstream, the middle reaches from Enshi to Ziqiu, and the east of Ziqiu is downstream. The catchment belongs to subtropical monsoon climate, rain and high temperature at the same period, high water period starts from April to September, accounting for $70 \%$ of the annual rainfall. The annual temperature is $15.2^{\circ} \mathrm{C}$, and the annual rainfall is $1561 \mathrm{~mm}$ (Chen et al. 2012).

The study area is dominantly composed of carbonate rock and evaporite, covering an area of $12,000 \mathrm{~km}^{2}$, accounting for $72 \%$ of the catchment. The middle and upper reaches are largely dominantly composed of Triassic and Permian formations, and the downstream are dominated by Cambrian formations (Fig.1). The catchment is composed of Sinian (Z), Cambrian ( () , Ordovician (O), Permian (P), Triassic (T) formations. While Lower Sinian formations mainly containing dolomite, Lower Cambrian formations containing limestone, Middle-Upper Cambrian formations mainly containing dolomite, Lower Ordovician formations containing bioclastic limestone and dolomite, Lower Permian formations mainly containing limestone, Lower Triassic formations mainly containing limestone, Middle Triassic formations containing dolomite, limestone and gypsum breccias. Karst aquifers are separated by sandstone and shale with tens of meters thickness, so each aquifer is relatively independent. Because carbonate rock is widely distributed, groundwater resource is abundant in the study area. There are 40 karst springs with a discharge larger than $500 \mathrm{~L} \cdot \mathrm{s}^{-1}$ according to previous statistics (Wang et al. 1995).

\section{Sampling And Analytical Methods}

There were 164 groundwater samples from 82 representative karst springs collected in high water period (July 2019) and low water period (December 2019), separately. The sampling location is shown in Fig.1. Among them, there were 4 groundwater samples from Sinian formations, 21 from Cambrian formations, 9 from Ordovician formations, 16 from Permian formations, and 32 from Triassic formations. Field study found that there is strong correlation between the chemical weathering rate and runoff (Kump et al. 2000), thus groundwater sampling in this study avoids the occurrence of precipitation event in a week. In order to accurately obtain the hydrochemical information of groundwater, the portable water quality parameter analyzer (AR8011 and PH828, Smart Sensor Company) was used to measure the groundwater temperature $(\mathrm{T}), \mathrm{pH}$ and electrical conductivity $(\mathrm{EC})$, with a resolution of $0.1^{\circ} \mathrm{C}$ and $0.01 \mathrm{pH}$ unit, respectively.

Before collecting groundwater samples, rinse the polyethylene (HDPE) bottle with groundwater 3 times, make sure that no bubbles remain in the bottle during storage. All groundwater samples were filtered through $0.45 \mu \mathrm{m}$ Acetate Fiber membrane filters, and then placed in 50ml HDPE bottles. The bottles for 
cation analysis were acidified to $\mathrm{pH}$ less than 2 with ultra-purified $\mathrm{HNO}_{3}$, and samples were sealed with parafilm and stored at $4^{\circ} \mathrm{C}$ in refrigerator before laboratory analysis.

Major cation ( $\mathrm{Ca}^{2+} \square \mathrm{Mg}^{2+} \square \mathrm{Na}^{+} \square \mathrm{K}^{+}$) were analyzed by ICP-OES (iCAP7600, Thermo Fisher Scientific, USA), anions $\left(\mathrm{SO}_{4}{ }^{2} \mathrm{DNO}_{3} \square \mathrm{Cl}\right.$ ) ) were analyzed by ion chromatograph (IC-2200, Thermo Fisher Scientific, USA), with a resolution of $0.01 \mathrm{mg} / \mathrm{L}$ for all ions. $\mathrm{HCO}_{3}{ }^{-}$was measured by the potentiometric titrimetric method, each sample was titrated three times, and the average error was $<5 \%$. All sample analyses were completed in the Geological Survey Experimental Center of China University of Geosciences, Wuhan. The analysis results were checked by calculating the normalized inorganic charge balance $\left(\mathrm{NICB}=\left(\mathrm{TZ}^{+}-\right.\right.$ $\left.\mathrm{TZ}^{-}\right) /\left(\mathrm{TZ}^{+}+\mathrm{TZ}^{-}\right)$), where $\mathrm{TZ}^{+}=2 \mathrm{Ca}^{2+}+2 \mathrm{Mg}^{2+}+\mathrm{Na}^{+}+\mathrm{K}^{+}, \mathrm{TZ}^{-}=\mathrm{HCO}_{3}{ }^{-}+2 \mathrm{SO}_{4}{ }^{2-}+\mathrm{NO}_{3}{ }^{-}+\mathrm{Cl}^{-}$, the unit of $\mathrm{TZ}^{+}$and $\mathrm{TZ}^{-}$ is meq. $\mathrm{L}^{-1}$. The NICB of all samples were within $\pm 5 \%$, except for the sample with a NICB of $8 \%$, which collected from Dragon Cave in Enshi. The mean value of NICB was $2 \%$, suggested that the analytical uncertainty in this study was relatively small, and the contribution of organic dissolution was not significant in the charge balance (Yu et al. 2015; Huang et al. 2021). The saturation index (SI) of calcite, dolomite, gypsum, and halite in groundwater was calculated by using the PhreeqC Interactive 3.0 software (Liu et al. 2020).

\section{Results And Discussion}

\subsection{General hydrochemistry}

The $\mathrm{pH}$ value of groundwater ranged from 6.50 to 9.40 , with an average of 7.98 . The concentration of $\mathrm{Ca}^{2+}$ in groundwater ranged from 27 to $118 \mathrm{mg} \cdot \mathrm{L}^{-1}$, with an average of $61 \mathrm{mg} \cdot \mathrm{L}^{-1} \cdot \mathrm{Mg}^{2+}$ concentration


accounted for $79 \%$ and $19 \%$ of total cation, respectively. The concentration of $\mathrm{Na}^{+}$in groundwater ranged from 0 to $9.7 \mathrm{mg} \cdot \mathrm{L}^{-1}$, with a mean value of $2.1 \mathrm{mg} \cdot \mathrm{L}^{-1}$, and $\mathrm{K}^{+}$varied from 0.2 to $3.8 \mathrm{mg} \cdot \mathrm{L}^{-1}$, with a mean

value of $1.1 \mathrm{mg} \cdot \mathrm{L}^{-1} \cdot \mathrm{HCO}_{3}{ }^{-}$was the predominant anion in groundwater, the concentration ranged from 81 to $483 \mathrm{mg} \cdot \mathrm{L}^{-1}$, with an average of $207 \mathrm{mg} \cdot \mathrm{L}^{-1}$, accounted for $86 \%$ of total anion. While $\mathrm{SO}_{4}{ }^{2-}$ varied dramatically, the concentration ranged from 3.4 to $218 \mathrm{mg} \cdot \mathrm{L}^{-1}$ (mean value of $19.3 \mathrm{mg} \cdot \mathrm{L}^{-1}$ ), with the maximum occurred in Dragon Cave in Enshi. The concentration of $\mathrm{NO}_{3}{ }^{-}$and $\mathrm{Cl}^{-}$varied from 0.4 to $39.5 \mathrm{mg} \cdot \mathrm{L}^{-1}$, and 0.1 to $10.6 \mathrm{mg} \cdot \mathrm{L}^{-1}$, separately.

The hydrochemical types of groundwater in the catchment included $\mathrm{Ca}-\mathrm{HCO}_{3}, \mathrm{Ca}+\mathrm{Mg}-\mathrm{HCO}_{3}$ and $\mathrm{Ca}-$ $\mathrm{HCO}_{3}+\mathrm{SO}_{4}$. While $\mathrm{Ca}+\mathrm{Mg}-\mathrm{HCO}_{3}$ type groundwater mainly distributed in the dolomite aquifers, and the hydrochemical type barely changed in different seasons. $\mathrm{Ca}-\mathrm{HCO}_{3}$ type groundwater mainly distributed in the limestone aquifers, and $\mathrm{Ca}-\mathrm{HCO}_{3}+\mathrm{SO}_{4}$ type groundwater distributed in Middle Triassic formations. Thereinto, the hydrochemical type of groundwater from Dragon Cave in Enshi was $\mathrm{Ca}-\mathrm{HCO}_{3}$ in high water period and changed to $\mathrm{Ca}-\mathrm{HCO}_{3}+\mathrm{SO}_{4}$ type in low water period, which is inferred to be caused by human pollution. 
The Piper trilinear diagram can objectively reflect the impact of different material sources (Piper. 1944; Vasić et al. 2021). Groundwater in Qingjiang catchment is characterized by high concentration of $\mathrm{Ca}^{2+}, \mathrm{Mg}^{2+}$ and $\mathrm{HCO}_{3}{ }^{-}$, indicates that carbonate weathering is dominant. According to the projection position in Fig.2, the samples distributed between limestone weathering end-member and dolomite weathering end-member. Moreover, the proportion of " $\mathrm{SO}_{4}{ }^{2-}+\mathrm{Cl}^{-\prime}$ is less than $40 \%$, with only one sample reach $54.9 \%$ in low water period, and the source of $\mathrm{SO}_{4}{ }^{2-}$ and $\mathrm{Cl}^{-}$may relate to sulfate mineral or human pollution (Frank et al. 2019). Meanwhile, the proportion of " $\mathrm{Na}+\mathrm{K}^{\prime}$ " and " $\mathrm{Cl}$ "' is less than $10 \%$, suggests that human pollution and evaporite minerals such as halite and sylvite have little impact on groundwater, and $\mathrm{SO}_{4}{ }^{2-}$ is more likely to derive from gypsum. Therefore, carbonate weathering is the main impact factor of groundwater chemistry, chemical weathering of evaporite is the secondary factor, and silicate weathering has less effect.

\subsection{Source identification of major ions}

The main source of ions in groundwater includes atmospheric input, chemical weathering of rock and human input (Gibbs. 1970; Han et al. 2004). Therefore, the molar ratios of $\left[\mathrm{Ca}^{2+}+\mathrm{Mg}^{2+}\right] /\left[\mathrm{HCO}_{3}{ }^{-}+\mathrm{SO}_{4}{ }^{2}\right]$ and $\left[\mathrm{Ca}^{2+}+\mathrm{Mg}^{2+}\right] /\left[\mathrm{HCO}_{3}\right]$ in groundwater can be used to determine the contribution of rock weathering. Fig.3a shows that all samples distributed close to $\left[\mathrm{Ca}^{2+}+\mathrm{Mg}^{2+}\right] /\left[\mathrm{HCO}_{3}{ }^{-}+\mathrm{SO}_{4}{ }^{2-}\right]=1$, which implies that $\left[\mathrm{Ca}^{2+}+\mathrm{Mg}^{2+}\right]$ and $\left[\mathrm{HCO}_{3}{ }^{-}+\mathrm{SO}_{4}{ }^{2-}\right]$ are equilibrium in groundwater. When groundwater is governed by carbonate weathering by carbonic acid only, $\left[\mathrm{Ca}^{2+}+\mathrm{Mg}^{2+}\right] /\left[\mathrm{HCO}_{3}{ }^{-}\right]$equivalent ratio of groundwater is equal to 1 (Pu et al. 2014; Yu et al. 2015). Meanwhile, $\left[\mathrm{Ca}^{2+}+\mathrm{Mg}^{2+}\right] /\left[\mathrm{HCO}_{3}{ }^{-}\right]$of all samples are less than 1 (Fig.3b), which indicates that the excess $\left[\mathrm{Ca}^{2+}+\mathrm{Mg}^{2+}\right] /\left[\mathrm{HCO}_{3}\right]$ is compensated by $\left[\mathrm{SO}_{4}{ }^{2-}\right]$. There are two sources of $\mathrm{SO}_{4}{ }^{2-}$, one is the dissolution of sulfate minerals, the other is sulfuric acid participate in the dissolution of carbonate rock ( $\mathrm{Li}$ et al. 2006; Xie et al. 2021). The average values of $\left[\mathrm{Ca}^{2+}+\mathrm{Mg}^{2+}\right] /\left[\mathrm{HCO}_{3}{ }^{-}\right.$ $\left.+\mathrm{SO}_{4}{ }^{2-}\right]$ and $\left[\mathrm{Ca}^{2+}+\mathrm{Mg}^{2+}\right] /\left[\mathrm{HCO}_{3}{ }^{-}\right]$in high water period are 1.035 and 1.148 , with an increase of 0.113 , while in low water period are 1.052 and 1.200 , with an increase of 0.148 , suggests that more [ $\left.\mathrm{SO}_{4}{ }^{2-}\right]$ compensate groundwater in low water period.

$\left[\mathrm{Ca}^{2+}\right] /\left[\mathrm{Mg}^{2+}\right]$ can reflect the relative proportion of calcite and dolomite dissolved in the aquifer. As shown in Fig.4a, groundwater in Sinian, Cambrian, and Ordovician aquifers has higher concentration of $\mathrm{Ca}^{2+}$ and $\mathrm{Mg}^{2+}$, and dissolution of dolomite provides $\mathrm{Mg}^{2+}$ for groundwater, which makes $\left[\mathrm{Ca}^{2+}\right] /\left[\mathrm{Mg}^{2+}\right]$ close to 1 . However, $\left[\mathrm{Ca}^{2+}\right] /\left[\mathrm{Mg}^{2+}\right]$ of groundwater from Permian and Triassic aquifers is significantly higher, with an average value of 10.69 in Permian aquifer, 12.98 in Triassic aquifer, indicates that calcite dissolution has a greater impact. While groundwater in Sinian and Cambrian aquifers shows a lower $\left[\mathrm{Ca}^{2+}\right] /\left[\mathrm{Mg}^{2+}\right]$ ratio compared with Ordovician aquifers, averaging 1.48, 1.98 and 4.69 in Sinian, Cambrian and Ordovician aquifers, respectively. It can be seen that the former two aquifers are affected by the dissolution of dolomite, the latter is affected by the dissolution of calcite and dolomite. 
Evaporite distributed in western regions of the study area, and gypsum was easily formed during the diagenesis of evaporite (Li. 1988). It is speculated that sulfate in groundwater derives from gypsum. The relationship between $\mathrm{Ca}^{2+}$ and $\mathrm{SO}_{4}{ }^{2-}$ is used to reveal the influence of gypsum or other sulfate mineral on groundwater chemistry (Frank et al. 2019). Groundwater in Permian and Triassic Jialingjiang formations has a higher $\mathrm{SO}_{4}{ }^{2-}$ background value, the average values are 19.0 and $34.1 \mathrm{mg} \cdot \mathrm{L}^{-1}$. According to Fig.5a, there are two reasons for the higher $\mathrm{SO}_{4}{ }^{2-}$ concentration. One is the coal-bearing formations associate with pyrite in Lower Permian Series, the dissolution of pyrite makes groundwater enrich $\mathrm{SO}_{4}{ }^{2-}$. The other reason is that karst breccias contain gypsum developed in Jialingjiang formations, the dissolution of gypsum causes groundwater rich in $\mathrm{SO}_{4}{ }^{2-}$.

When $\left[\mathrm{Ca}^{2+}+\mathrm{Mg}^{2+}\right]$ is completely balanced by $\left[\mathrm{HCO}_{3}{ }^{-}+\mathrm{SO}_{4}{ }^{2-}+\mathrm{NO}_{3}\right]$, the slope of $\left[\mathrm{Ca}^{2+}+\mathrm{Mg}^{2+}\right] /\left[\mathrm{HCO}_{3}{ }^{-}+\mathrm{SO}_{4}{ }^{2-}\right.$ $+\mathrm{NO}_{3}{ }^{-}$] trend line and $\mathrm{R}^{2}$ are equal to 1 , and the intercept is 0 . Fig.5b and Fig.3a show that $\left[\mathrm{Ca}^{2+}+\mathrm{Mg}^{2+}\right] /\left[\mathrm{HCO}_{3}{ }^{-}+\mathrm{SO}_{4}{ }^{2-}\right]$ and $\left[\mathrm{Ca}^{2+}+\mathrm{Mg}^{2+}\right] /\left[\mathrm{HCO}_{3}{ }^{-}+\mathrm{SO}_{4}{ }^{2-}+\mathrm{NO}_{3}{ }^{-}\right]$have a near perfect correlation. After considering the balance of $\left[\mathrm{NO}_{3}\right]$, the trend line slope changes from 0.97 to 1.0142 , and the correlation coefficient $\left(\mathrm{R}^{2}\right)$ is corrected from 0.9885 to 0.9923 , a smaller correction implies that $\mathrm{NO}_{3}{ }^{-}$has a limited impact on groundwater. Generally, $\mathrm{NO}_{3}{ }^{-}$derives from urban and agricultural pollution input, so its concentration can reveal the impact of human activities on hydrochemistry (Agrawal et al. 1999; Jeong. 2001). Therefore, the result shows that groundwater in the study area affected by human pollution is relatively small.

\subsection{Saturation Index}

The saturation index $(\mathrm{SI})$ is a method of material source analysis with a higher accuracy than ion ratio relationship, it can indicate whether minerals are dissolved or precipitated in groundwater (Wen et al. 2012; Mohamed et al. 2019). It is generally recognized that $S I$ is in equilibrium within the range of $0 \pm 0.5$ due to the errors of ions analysis and ion activity calculation (Ma. 2016). Based on the relationship between groundwater chemistry and $\mathrm{SI}$, it can be inferred which kinds of mineral provide material source for groundwater (Stradioto et al. 2020). The saturation index of calcite (Fig.6a) ranges from 0.15 to -0.97 , with an average value of -0.38 , shows that calcite is in equilibrium or under saturated. The saturation index of dolomite (Fig.6b) varies from 0.28 to -2.53 , with an average value $-1.37,87.2 \%$ of the groundwater samples are under saturated with respect to dolomite. The saturation index of gypsum (Fig.6c) and halite (Fig.6d) ranges from -1.15 to -3.17 and from -8.58 to -11.8 , indicates that gypsum and halite are under saturated in groundwater.

There is a positive correlation between saturation index and ion concentration, indicates that the dissolution of calcite, dolomite, gypsum and halite is the main source of $\mathrm{Ca}^{2+}, \mathrm{Mg}^{2+}, \mathrm{Na}^{+}, \mathrm{HCO}_{3}{ }^{-}, \mathrm{SO}_{4}{ }^{2-}, \mathrm{Cl}^{-}$ in groundwater (Santhanam et al. 2021). While the relationship between the saturation index and corresponding ion concentration in low water period is better than high water period. Because in different hydroperiod, seasonal change may lead to variations of groundwater circulation, which cause differences 
in water-rock interaction (Liu et al. 2007; Marco et al. 2013). The dynamic variations of groundwater level are more intense in high water period due to abundant recharge. Therefore, groundwater in karst aquifer flows faster (Frank et al. 2019), and water-rock interaction time is shorter. However, recharge reduces in low water period, groundwater alternates between conduit and matrix is slow, and groundwater lixiviation is more sufficient.

\subsection{Inverse geochemical modelling}

Geological background is the dominant factor of groundwater chemistry (Romanov et al. 2003; Liu et al. 2020). In order to study mineral transfer and its seasonal variation between water and rock, inverse geochemical modeling is used to simulate karst aquifers in different hydroperiod. Six representative simulation flow paths are selected: Flow path 1 is in the Triassic aquifer, starting with the Daye limestone aquifer and passes through the Jialingjiang gypsum-bearing dolomite aquifer; Flow path 2 is in the Jialingjiang aquifer; Flow path 3 is in the Daye aquifer; Flow path 4 is in the Permian limestone aquifer; Flow path 5 is in the Ordovician aquifer; Flow path 6 is in the Cambrian dolomite aquifer.

According to the geological background of the study area and saturation index analysis results, the determination of "possible mineral phases" in the inverse geochemical modeling are calcite, dolomite, gypsum and halite. Meanwhile, the karst groundwater system is in open state, and $\mathrm{CO}_{2}$ dissolves in groundwater and participates in rock weathering, therefore, $\mathrm{CO}_{2}$ is also the "possible mineral phase". Along the direction of groundwater flow in different aquifer, the starting point and ending point are selected to establish the inverse geochemical modeling, and the calculation results of mineral transfer are shown in Fig.7.

The modeling results show that calcite, dolomite and $\mathrm{CO}_{2}$ are the main mineral phases, and dissolution of dolomite reaches $33.39 \times 10^{-5} \mathrm{~mol} \cdot \mathrm{L}^{-1}$ in Flow path 6 . As for gypsum and halite, mineral transfer amounts are relatively small, dissolution of gypsum in Flow path 2 is only $5.375 \times 10^{-5} \mathrm{~mol} \cdot \mathrm{L}^{-1}$, which is the highest among all flow paths. Furthermore, the transfer amount of calcite, dolomite and $\mathrm{CO}_{2}$ are larger than 0 in Flow path 2, 3 and 4, indicates that the dissolution of calcite, dolomite and $\mathrm{CO}_{2}$ occurs in these flow paths. Thereinto, the dissolution of calcite in Flow path 3 and 4 is larger than dolomite, while the dissolution of calcite in Flow path 2 is less than dolomite. Because Flow path 2 flows through dolomite aquifer, Flow path 3 and 4 are in limestone aquifers. In addition, the dissolution of dolomite is greater than the precipitation of calcite in Flow path 1, 2, 5 and 6, which flows through dolomite formations. Therefore, the lithology of aquifers plays an important role in Qingjiang catchment, carbonate minerals transfer amount is larger than other minerals in karst aquifers, and it also determines the transfer amount of calcite and dolomite.

Generally, the phenomenon that dolomite and gypsum dissolves as well as calcite precipitates is called dedolomitization (Baumann et al. 2019). Among all flow paths, the transfers amount of calcite in Flow path 1, 5 and 6 is less than 0 in both high and low water period, indicates that precipitation occurs in these flow paths. At the same time, the transfer amount of dolomite, gypsum, and $\mathrm{CO}_{2}$ is larger than 0 , 
which shows that dissolution occurs in these flow paths. When the gypsum dissolves, the concentration of $\mathrm{Ca}^{2+}$ and $\mathrm{SO}_{4}{ }^{2-}$ in groundwater increases, and the common ion effect of $\mathrm{Ca}^{2+}$ occurs. Under the influence of common ion effect, calcite precipitates, which promotes the dissolution of dolomite and leads to the increase of $\mathrm{Ca}^{2+}, \mathrm{Mg}^{2+}$ and $\mathrm{SO}_{4}{ }^{2-}$ in groundwater (Wu et al. 2020).

\subsection{Hydrogeochemical Process}

According to the modeling results, the water-rock interactions in Qingjiang catchment include chemical weathering of carbonate rock and evaporite. Carbonate weathering is manifested in two forms, one is the co-dissolution of calcite and dolomite, the other is dedolomitization. The hydrogeochemical process occurs in Flow path 3 and 4 is the co-dissolution of calcite and dolomite, the reaction equations are indicated by Eq. (1) and Eq. (2) (Eq. (1): $\mathrm{CaCO}_{3}+\mathrm{CO}_{2}+\mathrm{H}_{2} \mathrm{O} \rightarrow 2 \mathrm{Ca}^{2+}+2 \mathrm{HCO}_{3}$; Eq. (2): $\mathrm{CaMg}\left(\mathrm{CO}_{3}\right)_{2}+2 \mathrm{CO}_{2}+$ $2 \mathrm{H}_{2} \mathrm{O} \rightarrow \mathrm{Ca}^{2+}+\mathrm{Mg}^{2+}+4 \mathrm{HCO}_{3}{ }^{-}$). According to Eq. (1) and Eq. (2), the ratio between $\mathrm{CaCO}_{3}$ and $\mathrm{CO}_{2}$ in the dissolution of calcite is $1: 1$; while the ratio between $\mathrm{CaMg}\left(\mathrm{CO}_{3}\right)_{2}$ and $\mathrm{CO}_{2}$ in the dissolution of dolomite is 1:2. The dissolved quantity of $\mathrm{CO}_{2}$ in Flow path 3 and 4 is approximately twice as much as the sum of calcite and dolomite, indicates that $\mathrm{CO}_{2}$ mainly participates in the co-dissolution of calcite and dolomite. However, dedolomitization occurs in Flow path 1, 5, and 6 which flow through dolomite aquifers, and the reaction equation is indicated by Eq. (3): $\mathrm{mCaMg}\left(\mathrm{CO}_{3}\right)_{2}+\mathrm{nCa}^{2+}+\mathrm{nSO}_{4}{ }^{2-} \rightarrow \mathrm{mMg}^{2+}+$ $\mathrm{nSO}_{4}{ }^{2-}+2 \mathrm{mCaCO}_{3}+(\mathrm{m}-\mathrm{n}) \mathrm{HCO}_{3}{ }^{-}(\mathrm{m} \geq \mathrm{n})$. Therefore, dedolomitization is widespread in the flow path which flows through dolomite aquifer in the study area. The dissolution of gypsum is under saturated and the concentration of $\mathrm{Ca}^{2+}$ and $\mathrm{SO}_{4}{ }^{2-}$ in groundwater increases. Eq. (3) proceeds towards right due to the dissolution of gypsum, as calcite precipitates, the dissolution of dolomite is promoted

However, the flow path of an underground river in dolomite aquifer shows an opposite characteristic of carbonate minerals. The starting point and ending point of Flow path 2 are the entrance and discharge of the largest underground river in Qingjiang catchment, and Flow path 1 is located in the recharge area of the underground river. As the results show, dedolomitization occurs in Flow path 1, and the transfer amount of carbonate minerals during high water period is larger than low water period. Whereas, the codissolution of calcite and dolomite occurs in Flow path 2, and the transfer amount of carbonate minerals is larger in low water period. Because Flow path 2 is in the conduit of the underground river, which has a faster flow, and carbonate minerals are likely to dissolve. Whereas, more groundwater with sufficient lixiviation enters the conduit in low water period. Under the circumstance of strong groundwater hydrodynamic, soluble minerals continue to dissolve and transport with groundwater, results in codissolution of calcite and dolomite (Bullen et al. 1998). Furthermore, the role of hydrodynamics change still has not drawn enough attention in previous studies of hydrogeochemical process in karst area.

The modeling results reflect the characteristics of water-rock interaction in karst aquifer. Groundwater is composed of rapid flow in conduit in high water period, while fissure flow and matrix flow were collected to conduit in low water period, with a sufficient water-rock interaction. Therefore, the transfer amount of calcite, dolomite and $\mathrm{CO}_{2}$ varies with the seasons, which is higher in low water period. 
The dissolution of evaporite, karstification and heavy rain can promote the dedolomitization process (Nader et al. 2008). However, dedolomitization cannot be simply considered that dolomite dissolution and calcite precipitation proceed at the same time (Evamy. 1967). In the dedolomitization reaction experiment involved in gypsum, no calcite was found in the dolomite dissolution residues, indicates that the dedolomitization is not simultaneous reaction of dolomite and calcite, but $\mathrm{Mg}$ continuously precipitates first, then dolomite is rich in Ca gradually, finally turns into calcite (Deng et al『 1993). The lithology of Jialingjiang formations in the study area is carbonate rock and evaporite. When Jialingjiang formations deposited, the paleoclimatic was hot and arid, and the South China Marine Transgression provided sufficient seawater. As seawater evaporated and concentrated, calcite, dolomite, gypsum, and halite were precipitated successively (Zhong et al. 2020). Seawater is rich in seven kinds of ions: $\mathrm{Ca}^{2+}, \mathrm{Mg}^{2+}, \mathrm{Na}^{+}, \mathrm{K}^{+}, \mathrm{HCO}_{3}{ }^{-}, \mathrm{SO}_{4}{ }^{2-}$ and $\mathrm{Cl}^{-}$. When seawater evaporates and concentrates, calcite precipitates first, $\mathrm{Ca}^{2+}$ in seawater decreases. Marine transgression provides $\mathrm{HCO}_{3}{ }^{-}$continuously, then seawater becomes brine which enriches $\mathrm{Mg}^{2+}$ and $\mathrm{HCO}_{3}{ }^{-}$. Brine provides material source for the precipitation of dolomite. After a certain amount of dolomite precipitates, brine becomes metamorphosis and rich in $\mathrm{Ca}^{2+}$ and $\mathrm{Mg}^{2+}$, when metamorphic brine mixed with normal brine, gypsum precipitates (Ayora et al. 2001).

In the study area, gypsum plays a secondary important mineral role in hydrogeochemical processes and has a tendency to dissolve in each aquifer. Especially for Jialingjiang aquifer, gypsum dissolution is much higher than other aquifers, and the dissolution of gypsum in Flow path 1 is $11.49 \mu \mathrm{mol} \cdot \mathrm{L}^{-1}$ (high water period) and $24.49 \mu \mathrm{mol} \cdot \mathrm{L}^{-1}$ (low water period). As for the Flow path 2 is $21.72 \mu \mathrm{mol} \cdot \mathrm{L}^{-1}$ (high water period) and $53.75 \mu \mathrm{mol} \cdot \mathrm{L}^{-1}$ (low water period). Although the level of gypsum is low in aquifer, it still affects the chemical composition of groundwater, because the weathering rate of evaporite and carbonate rock is 80 and 12 times faster than that of silicate rock (Meybeck. 1987). The inverse geochemical modeling results show that gypsum participates in the chemical evolution of groundwater and cannot be neglected.

\subsection{Quantify the impact of carbonic acid, sulfuric and nitric acids in carbonate weathering after} modifying by evaporite and atmospheric input

Generally, research of carbonate weathering is chosen in the catchment that the influence of evaporite is slight, because except for carbonate mineral, gypsum dissolution and atmospheric input provide more $\mathrm{Ca}^{2+}$ for groundwater. Therefore, this study attempts to calculate the contribution of sulfuric acid and nitric acid after modified by evaporite. It is assumed that all $\mathrm{Ca}^{2+}, \mathrm{Mg}^{2+}$ and $\mathrm{HCO}_{3}{ }^{-}$in groundwater are derived from carbonate weathering, and thereinto $k_{1} \mathrm{~mol} \cdot \mathrm{L}^{-1}$ carbonic acid, $k_{2} \mathrm{~mol} / \mathrm{L}$ nitric acid, and $k_{3}$ $\mathrm{mol} / \mathrm{L}$ sulfuric acid. Based on the conservation of mass, carbonate weathering involved in carbonic acid, sulfuric acid and nitric acid can be described as Eq. (4): $\left(k_{1}+k_{2}+2 k_{3}\right) \mathrm{Ca}_{\mathrm{x}} \mathrm{Mg}_{(1-\mathrm{x})} \mathrm{CO}_{3}+k_{1} \mathrm{H}_{2} \mathrm{CO}_{3}+$ $k_{2} \mathrm{HNO}_{3}+k_{3} \mathrm{H}_{2} \mathrm{SO}_{4} \rightarrow\left(k_{1}+k_{2}+2 k_{3}\right) \times \mathrm{Ca}^{2+}+\left(k_{1}+k_{2}+2 k_{3}\right)(1-\mathrm{x}) \mathrm{Mg}^{2+}+\left(2 k_{1}+k_{2}+2 k_{3}\right) \mathrm{HCO}_{3}{ }^{-}+k_{2} \mathrm{NO}_{3}{ }^{-}+k_{3} \mathrm{SO}_{4}{ }^{2-}$ $(0 \leq x \leq 1)$ (Xie et al. 2021). The concentration of $\left[\mathrm{Ca}^{2+}+\mathrm{Mg}^{2+}\right]$ and $\left[\mathrm{HCO}_{3}{ }^{-}\right]$can be calculated as Eq. (5) and 
Eq. (6): $\left[\mathrm{Ca}^{2+}+\mathrm{Mg}^{2+}\right]_{\text {carb }}=k_{1}+k_{2}+2 k_{3}=\left[\mathrm{Ca}^{2+}+\mathrm{Mg}^{2+}\right]_{\text {groundwater }}\left[\mathrm{Ca}^{2+}+\mathrm{Mg}^{2+}\right]_{\text {sil }^{-}}\left[\mathrm{Ca}^{2+}+\mathrm{Mg}^{2+}\right]_{\mathrm{eva}^{-}}$

$\left[\mathrm{Ca}^{2+}+\mathrm{Mg}^{2+}\right]_{\text {rain }} ;\left[\mathrm{HCO}_{3}\right]_{\mathrm{carb}}=2 k_{1}+k_{2}+2 k_{3}=\left[\mathrm{HCO}_{3}\right]_{\text {groundwater }}\left[\mathrm{HCO}_{3}\right]_{\mathrm{sil}^{-}}\left[\mathrm{HCO}_{3}\right]_{\text {rain }}$. According to Eq. (5) and Eq. (6), carbonate weathering by carbonic acid can be calculated as follow: $k_{1}=\left[\mathrm{HCO}_{3}{ }^{-}\right]_{\text {carb }}{ }^{-}$ $\left[\mathrm{Ca}^{2+}+\mathrm{Mg}^{2+}\right]_{\mathrm{carb}}$, and the contribution of carbonate weathering by carbonic acid can be calculated by $k_{1} /\left(k_{1}+k_{2}+2 k_{3}\right)$. Furthermore, carbonate weathering by sulfuric acid and nitric acid cannot be calculated separately, thus the contribution of carbonate weathering by sulfuric acid and nitric acid can be calculated by $\left(k_{2}+2 k_{3}\right) /\left(k_{1}+k_{2}+2 k_{3}\right)$ (Xie et al. 2021).

Qingjiang catchment is located in the western interior of Hubei Province, so the influence of the ocean is neglected. Groundwater recharge mainly comes from atmospheric input, therefore, ions derive from atmosphere can be calculated by referring to the concentration ratio of $\mathrm{Cl}^{-}$and other ions of rainwater (Moon et al. 2007). The atmospheric input correction is calculated as Eq. (7): $[\mathrm{X}]_{\text {rain }}=$ $\left[\mathrm{Cl}^{-}\right]_{\text {rain }} \cdot\left(\mathrm{X} / \mathrm{Cl}^{-}\right)_{\text {atm }}$, where $\left[\mathrm{Cl}^{-}\right]_{\text {rain }}$ is the concentration of $\mathrm{Cl}^{-}$of rainwater, $\left(\mathrm{X} / \mathrm{Cl}^{-}\right)_{\text {atm }}$ is the molar ratio of other ion and $\mathrm{Cl}^{-}$. Due to a small quantity of rainwater samples in this study, the average values of each ion and $\mathrm{Cl}^{-}$of rainwater were quoted from $\mathrm{Han}$ (2006)'s research in southwest China, with $\mathrm{Ca}^{2+} / \mathrm{Cl}^{-}$ $=2.67, \mathrm{Mg}^{2+} / \mathrm{Cl}^{-}=0.60, \mathrm{Na}^{+} / \mathrm{Cl}^{-}=0.19, \mathrm{~K}^{+} / \mathrm{Cl}^{-}=0.52, \mathrm{SO}_{4}{ }^{2-} / \mathrm{Cl}^{-}=4.44, \mathrm{NO}_{3}{ }^{-} / \mathrm{Cl}^{-}=2.28$. The calculated results show that the contribution of groundwater chemical composition from rainwater ranges from $1.1 \%$ to $4.8 \%$, indicating that atmospheric input contributes little to groundwater solutes. Saturation index analysis shows that gypsum and halite are the main evaporite minerals, evaporite weathering does not produce $\mathrm{Mg}^{2+}$, thus $\left[\mathrm{Ca}^{2+}+\mathrm{Mg}^{2+}\right]_{\mathrm{eva}}$ is approximately equal to the $\mathrm{Ca}^{2+}$ produced by gypsum dissolution. Inverse geochemical modeling is used to calculate the transfer amount of gypsum from atmosphere to each aquifer, and the average value is selected for the Sinian aquifer that has not been simulated, and the calculated results are presented in Table 1.

The contribution of carbonate weathering by carbonic acid, sulfate acid and nitric acid is shown in Fig.8. The contribution of carbonate weathering by carbonic acid varies from $34.6 \%$ to $89.9 \%$ in high water period, with an average of $70.9 \%$, and from $31.3 \%$ to $91.8 \%$, with an average of $70.0 \%$ in low water period. While the contribution of carbonate weathering by sulfate acid and nitric acid varies from $10.2 \%$ to $65.4 \%$, with an average of $29.1 \%$ in high water period, and from $8.2 \%$ to $68.7 \%$, with an average of $30.0 \%$ in low water period, respectively. However, in low water period, the contribution of sulfate acid and nitric acid in Enshi Dragon Cave is $100 \%$, and garbage pollution event has been reported, so statistics eliminate this sample.

According to the test results, the concentration of nitrate in rainwater is $1.18 \mathrm{mg} \cdot \mathrm{L}^{-1}$, while the average concentration of nitrate in groundwater is $11.91 \mathrm{mg} \cdot \mathrm{L}^{-1}$, indicating that atmospheric input is less. Karst depressions and trough valleys are widely distributed in the recharged area of Qingjiang catchment (Wang et al. 1995). Flat karst tough valley is often used as an agricultural land, agricultural effluent with higher $\mathrm{NO}_{3}{ }^{-}$concentration transports underground through the ponor and provides material source for nitric acid (Kačaroğlu. 1999). Due to the cascaded hydropower project in mainstream, the 
impact of fossil fuel pollution is slight (Sun et al. 2016), and no acid deposition events have been reported in the study area. Therefore, it is believed that $\mathrm{SO}_{4}{ }^{2-}$ mainly derived from gypsum dissolution, which is consistent with the previous analysis.

The results show that carbonate weathering is mainly controlled by carbonic acid, while the contribution of sulfate acid and nitric acid in low water period is slightly higher than high water period. Except for $\mathrm{HCO}_{3}{ }^{-}$, the conductivity and major ion concentration of groundwater in low water period are higher, indicating that the groundwater is affected by the dilution effect of rainwater in high water period. It may cause a higher contribution of sulfate acid and nitric acid in carbonate weathering during low water period. However, the results of this study are contrary to Wang (2021)'s research in Yangtze River basin, which shows that sulfate acid and nitric acid have a greater influence on carbonate weathering in Qingjiang river during high water period. The contribution of carbonate weathering involved in carbonic acid is about $55 \%$ (high water period) and 60\% (low water period) in Wang (2021)'s research. Sulfate acid and nitric acid input from river is significantly greater than groundwater, but this study shows that sulfate acid and nitric acid input from groundwater cannot be neglected. This view provides new ideas for the chemical weathering of carbonate rocks.

According to the statistics of calculated results and groundwater discharge (Fig.9), there are 52 karst springs having a discharge less than $50 \mathrm{~L} \cdot \mathrm{s}^{-1}$. For these springs, the contribution of sulfate acid and nitric acid to carbonate weathering shows little difference, with a mean value of $31.9 \%$ and $31.8 \%$ in high and low water period, respectively. There are 29 karst springs and underground rivers with a discharge larger than $50 \mathrm{~L} \cdot \mathrm{s}^{-1}$ in low water period, with an average value of $39.0 \%$ in high water period, but only $35.3 \%$ in high water period. Thereinto, 17 samples have a greater contribution of sulfate acid and nitric acid involved in carbonate weathering during low water period. It is notable that in the aquifers with larger groundwater discharge, there is a positive correlation between spring discharge and the contribution of sulfate acid and nitric acid to carbonate weathering. This means that karst springs and underground rivers with strong underground runoff are more susceptible to the sulfate acid and nitric acid. Due to the dual effects of conduit flow and matrix flow in karst groundwater, the difference of aquifer medium is an important factor that affects carbonate weathering. Due to less recharge, groundwater is mainly composed of matrix flow with a longer water-rock interaction in low water period, which has higher concentration of $\mathrm{NO}_{3}{ }^{-}$and $\mathrm{SO}_{4}{ }^{2-}$. In order to accurately estimates carbonate weathering by sulfate acid and nitric acid in karst area, the impact of groundwater should be considered, and its role is worthy of further study.

\section{Table $1[\mathrm{Ca} 2++\mathrm{Mg} 2+]$ eva assigned to each aquifer}


Hydroperiod

$/ 10^{-5}$

$\mathrm{mol} \cdot \mathrm{L}^{-1}$
Triassic Jialingjiang formations
Triassic

Daye

formations
Permian Ordovician formations
Cambrian

formations formations
Sinian

formations
High water period

\section{Low water}

period
10.900

15.250
7.426

7.582
8.868

12.234
8.796

12.910

9.811

\section{Conclusions}

According to the hydrochemical analysis of karst groundwater in Qingjiang Catchment, the dissolution of calcite, dolomite, gypsum and halite provides major ions for groundwater. Carbonate weathering is the main source of groundwater, followed by evaporite weathering and atmospheric input. There are two types of water-rock reactions occurred in the aquifer. One is co-dissolution of calcite and dolomite, which shows that the dissolution of calcite is larger than dolomite in limestone aquifer, while dolomite aquifer is the opposite. The other is dedolomitization, which is widespread in dolomite aquifers, manifested by dolomite and gypsum dissolution, as well as calcite precipitation. As a secondary mineral, the dissolution of gypsum causes common ion effect of $\mathrm{Ca}^{2+}$ and promotes dedolomitization.

In the calculation of carbonate weathering after modifying by evaporite and atmospheric input, the contribution of carbonate weathering by carbonic acid varied from $34.6 \%$ to $89.9 \%$, with an average of $70.9 \%$ in high water period, and varied from $31.3 \%$ to $91.8 \%$, with an average of $70.0 \%$ in low water period, respectively. Statistics show that there is a positive correlation between karst springs discharge and carbonate weathering. The contribution of sulfate acid and nitric acid involved in carbonate weathering is higher in the aquifers with a larger groundwater discharge. Furthermore, the contribution of sulfate acid and nitric acid is higher in low water period than high water period. Because karst aquifer has a characteristic of special medium, groundwater recharge is abundant in high water period and mainly composed of conduit flow, which has a rapid water-rock interaction. However, groundwater recharge is less in low water period and mainly composed of matrix flow with longer water-rock interaction. Therefore, the role of sulfuric acid and nitric acid in karst area with abundant groundwater resources should not be ignored and worthy of further study.

\section{Declarations}

\section{Acknowledgments}

This work was supported by the Project of the China Geological Survey (DD20190824), the National Key Research and Developmental Program of China (2016YFC0502302). The authors would like to express special thanks to the editors and the anonymous reviewers for offering valuable suggestions, which were 
helpful for improving the quality of the manuscript. Our special thanks are given to Yinong Peng, Suqing Deng and Wei Sun for their help with field and laboratory work.

\section{References}

Agrawal GD, Lunkad SK, Malkhed T. (1999) Diffuse agricultural nitrate pollution of groundwaters in India. Water Science and Technology 39:67-75. https://doi.org/10.2166/wst.1999.0138

Ayora C, Cendon DI, Taberner C, Pueyo JJ. (2001) Brine-mineral reactions in evaporite basins: Implications for the composition of ancient oceans. Geology 29:251-254. https://doi.org/10.1130/00917613(2001)029<0251:BMRIEB>2.0.CO;2

Baumann GO, Vital M, Melisa G, Sebastián G, Héctor M, Daniel EM. (2019) Hydrogeochemical modeling and dedolomitization processes in the Patagonian Boulders and Patagonia Formation in the eastern Patagonia, Argentina. Environmental Earth Sciences 78. https://doi.org/10.1007/s12665-019-8583-7

Bullen TD, Kendall C. (1998) Isotope tracers in Catchment Hydrology. In: Kendall C., McDonnell J.J. (eds.) Tracing of weathering reactions and water flowpaths: A multi-isotope approach. Elsevier Science, pp 611646. https://doi.org/10.1016/B978-0-444-81546-0.50025-2

Chen H, Xiang TT, Zhou X, Xu CY. (2012) Impacts of climate change on the Qingjiang watershed's runoff change trend in China. Stochastic Environmental Research and Risk Assessment 26:847-858. https://doi.org/10.1007\%2Fs00477-011-0524-2

Deng M, Tang MS. (1993) Mechanism of dedolomitization and expansion of dolomitic rocks. Cement and Concrete Research 23(6):1397-1408.

Du ZQ, Linghu B, Ling F, Li WB, Tian WD, Wang HL, Gui YM, Sun BY, Zhang XM. (2012) Estimating surface water area changes using time-series Landsat data in the Qingjiang river basin, China. Journal of Applied Remote Sensing 6. https://doi.org/10.1117\%2F1.jrs.6.063609

Evamy BD. (1967) Dedolomitization and the development of rhombohedral pores in limestones. Journal of Sedimentary Research 37:1204-1215

Frank S, Goeppert N, Ohmer M, Goldscheider N. (2019) Sulfate variations as a natural tracer for conduitmatrix interaction in a complex karst aquifer. Hydrological Processes 33.

https://doi.org/10.1002/hyp.13400

Gaillardet J, Dupre B, Louvat P, Allegre CJ. (1999) Global silicate weathering and $\mathrm{CO}_{2}$ consumption rates deduced from the chemistry of large rivers. Chemical Geology 159:3-30. https://doi.org/10.1016/S00092541(99)00031-5 
Garcia-Rios M, Cama J, Luquot L, Soler JM. (2014) Interaction between $\mathrm{CO}_{2}$-rich sulfate solutions and carbonate reservoir rocks from atmospheric to supercritical $\mathrm{CO}_{2}$ conditions: experiments and modeling. Chemical Geology 383:107-122. https://doi.org/10.1016/j.chemgeo.2014.06.004

Gibbs RJ. (1970) Mechanisms controlling world water chemistry. Science, 170:1088-1090

Han GL, Liu CQ. (2004) Water geochemistry controlled by carbonate dissolution: A study of the river waters draining karst-dominated terrain, Guizhou province, China. Chemical Geology 204:1-21. https://doi.org/10.1016/j.chemgeo.2003.09.009

Han GL, Liu CQ. (2006) Strontium isotope and major ion chemistry of the rainwaters from Guiyang, Guizhou Province, China. Science of the Total Environment 364:165-174. https://doi.org/10.1016/j.scitotenv.2005.06.025

Hartmann J, Jansen N, Dürr HH, Kempe S, Köhler P. (2009) Global $\mathrm{CO}_{2}$ consumption by chemical weathering: What is the contribution of highly active weathering regions? Global and Planetary Change 69:185-194. https://doi.org/10.1016/j.gloplacha.2009.07.007

Huang QB, Qin XQ, Cheng RR, Li TF, Wu HY, Liao HW. (2021) Investigation of the hydrogeochemical processes and regional evolution of karst groundwater in Liulin Spring catchment, northern China. Environmental Earth Sciences 80. https://doi.org/10.1007/s12665-020-09280-0

Jeong CH. (2001) Effect of land use and urbanization on hydrochemistry and contamination of groundwater from Taejon area, Korea. Journal of Hydrology 253:194-210.

https://doi.org/10.1016\%2Fs0022-1694\%2801\%2900481-4

Jiang ZQ, Qin H, Ji CM, Feng ZK, Zhou JZ. (2017) Two Dimension Reduction Methods for Multidimensional Dynamic Programming and Its Application in Cascade Reservoirs Operation Optimization. Water 9:634. https://doi.org/10.3390/w9090634

Kačaroğlu F. (1999) Review of groundwater pollution and protection in karst areas. Water, Air, and Soil Pollution 113:337-356. https://doi.org/10.1023/A:1005014532330

Kump LR, Brantley SL, Arthur MA. (2000) Chemical Weathering, Atmospheric $\mathrm{CO}_{2}$, and Climate. Annual Review of Earth \& Planetary Sciences 28:611-667. https://doi.org/10.1146/annurev.earth.28.1.611

Li SL, Gaillardet J, Han GL, Calmels D, Liu C. (2006) Sulfuric acid as a weathering agent of carbonate weathering constrained by $\delta^{13} \mathrm{C}$ : examples from Southwest China. Chinese Journal of Geochemistry 25:270-271. https://doi.org/10.1007/BF02840269

Li SR. (1988) The tectonic factors conducive to the formations of evaporites during the indosinian in Hubei province and its adjacent areas are discussed. Acta Geologica Sinica 2:30-37 (in Chinese) 
Li XD, Liu CQ, Liu XL, Bao LR. (2011) Identification of dissolved sulfate sources and the role of sulfuric acid in carbonate weathering using dual-isotopic data from the Jialing River, Southwest China. Journal of Asian Earth Sciences 42:370-380. https://doi.org/10.1016/j.jseaes.2011.06.002

Li YQ, Li SJ, He DF, Gao J, Wang YC, Huang HY, Zhang JT, Zhang Y. (2020) Middle Triassic tectonosedimentary development of Sichuan Basin: Insights into the cratonic differentiation. Geological Journal 56:1858-1878. https://doi.org/10.1002/gj.4033

Liu J, Wang H, Jin DW, Xu F, Zhao CH. (2020) Hydrochemical characteristics and evolution processes of karst groundwater in Carboniferous Taiyuan formation in the Pingdingshan coalfield. Environmental Earth Sciences 79. https://doi.org/10.1007/s12665-020-8898-4

Liu J, Zhong J, Chen S, Xu S, Li SL. (2021) Hydrological and biogeochemical controls on temporal variations of dissolved carbon and solutes in a karst river, South China. Environmental Sciences Europe 33:53. https://doi.org/10.1186/s12302-021-00495-x

Liu ZH, Li Q, Sun HL, Wang JL. (2007) Seasonal, diurnal and storm-scale hydrochemical variations of typical epikarst springs in subtropical karst areas of SW China: Soil $\mathrm{CO}_{2}$ and dilution effects. Journal of Hydrology 337:207-223. https://doi.org/10.1016/j.jhydrol.2007.01.034

Liu ZH, Dreybrodt W, Liu H. (2011) Atmospheric $\mathrm{CO}_{2}$ sink: Silicate weathering or carbonate weathering? Applied Geochemistry 26:292-294. https://doi.org/10.1016/j.apgeochem.2011.03.085

Ma HY. (2016) Major ion chemistry of groundwater in the Sangong River Watershed, Northwestern China. Environmental Earth Sciences 75. https://doi.org/10.1007/s12665-016-5321-2

Maher K, Chamberlain CP. (2014) Hydrologic regulation of chemical weathering and the geologic carbon cycle. Science 343:1502-1504

Marco T, Barbara P, Marco P, Michele S. (2013) Long-term spatio-temporal hydrochemical and ${ }^{222} \mathrm{Rn}$ tracing to investigate groundwater flow and water-rock interaction in the Gran Sasso (central Italy) carbonate aquifer. Hydrogeology Journal 21:1447-1467. https://doi.org/10.1007/s10040-013-1023-y

Martin JB. (2017) Carbonate minerals in the global carbon cycle. Chemical Geology 449:5872. https://doi.org/10.1016/j.chemgeo.2016.11.029

Meybeck M. (1987) Global chemical weathering of surficial rocks estimated from river dissolved loads. American Journal of Science 278:401-428. https:// doi.org/10.1016/0198-0254(87)95902-4

Mohamed EA, Fathy A, Karim M, Talal A. (2019) Hydrochemical equilibrium and statistical approaches as effective tools for identifying groundwater evolution and pollution sources in arid areas. Geosciences Journal 23:299-314. https://doi.org/10.1007/s12303-018-0039-7 
Moon S, Huh Y, Zaitsev A. (2009) Hydrochemistry of the Amur River: Weathering in a Northern Temperate Basin. Aquatic Geochemistry 15:497. https://doi.org/10.1007/s10498-009-9063-6

Moon S, Huh Y, Qin J, Pho NV. (2007) Chemical weathering in the Hong (Red) River basin: Rates of silicate weathering and their controlling factors. Geochimica et Cosmochimica Acta 71:1411-1430. https://doi.org/10.1016/j.gca.2006.12.004

Nader FH, Swennen R, Keppens E. (2008) Calcitization/dedolomitization of Jurassic dolostones (Lebanon): Results from petrographic and sequential geochemical analyses. Sedimentology 55:14671485. https://doi.org/10.1111/j.1365-3091.2008.00953.x

Piper AM. (1944) A graphic procedure in the geochemical interpretation of water-analyses. Transactions American Geophysical Union 25:914-923. https://doi.org/10.1029/TR025i006p00914

Pu JB, Cao M, Zhang YZ, Yuan DX, Zhao HP. (2014) Hydrochemical indications of human impact on karst groundwater in a subtropical karst area, Chongqing, China. Environmental Earth Sciences 72:1683-1695. https://doi.org/10.1007/s12665-014-3073-4

Romanov D, Gabrovsek F, Dreybrodt W. (2003) The impact of hydrochemical boundary conditions on the evolution of limestone karst aquifers. Journal of Hydrology 276:240-253. https://doi.org/10.1016/S00221694(03)00058-1

Santhanam H, Karthikeyan ARM. (2021) Saturation indices of aqueous mineral phases as proxies of seasonal dynamics of a transitional water ecosystem using a geochemical modeling approach. Modeling Earth Systems and Environment 7:1813-1829. https://doi.org/10.1007/s40808-020-00910-x

Soulsby C, Tetzlaff D, Van den bedem N, Malcolm IA, Bacon PJ, Youngson AF. (2007) Inferring groundwater influences on surface water in montane catchments from hydrochemical surveys of springs and streamwaters. Journal of Hydrology 333:199-213. https://doi.org/10.1016/j.jhydrol.2006.08.016

Stradioto MR, Teramoto EH, Chang HK. (2020) Rock-solute reaction mass balance of water flowing within an aquifer system with geochemical stratification. Applied Geochemistry 123: 104784. https://doi.org/10.1016/j.apgeochem.2020.104784

Sun PA, He SY, Yu S, Pu JB, Yuan YQ, Zhang C. (2021) Dynamics in riverine inorganic and organic carbon based on carbonate weathering coupled with aquatic photosynthesis in a karst catchment, Southwest China. Water Research 189:116658. https://doi.org/10.1016/j.watres.2020.116658

Sun Y, Wan JW, Yang SY, Xue XH, Huang K. (2016) Influences of water conservancy and hydropower projects on runoff in Qingjiang river upstream basin. Journal of Earth Science 27:110-116. https://doi.org/10.1007/s12583-016-0640-5 
Torres M, West AJ, Li GJ. (2014) Sulphide oxidation and carbonate dissolution as a source of $\mathrm{CO}_{2}$ over geological timescales. Nature 507:346-349. https://www.nature.com/articles/nature13030

Vasić L, Živojinovic DŽ, Rajaković-Ognjanović V, Huang F, Cao JH. (2021) The subthermal potential of karstic groundwater of Kučaj-Beljanica region in Serbia estimated by the multivariate analysis.

Environmental Earth Sciences 80. https://doi.org/10.1007/s12665-021-09392-1

Wang B, Lee XQ, Yuan HL, Zhou H, Cheng HG, Cheng JZ, Zhou ZH, Xing Y, Fang B, Zhang LK, Yang F. (2012) Distinct patterns of chemical weathering in the drainage basins of the Huanghe and Xijiang River, China: Evidence from chemical and Sr-isotopic compositions. Journal of Asian Earth Sciences 59:219230. https://doi.org/10.1016/j.jseaes.2012.07.005

Wang Q, Yu S, Jiang PP, Sun PA. (2021) Water chemical characteristics and influence of exogenous acids in the Yangtze River basin. Environmental Science 1-17. https://doi.org/10.13227/j.hjkx.202012040 (in Chinese)

Wang ZY, Shen JF, Xu RC, Shi BX. (1995) Karst landscapes and their evolution in reaches of the Qingjiang river watershed. Earth Science 4:439-444 (in Chinese)

Wen XH, Diao M, Wang D, Gao M. (2012) Hydrochemical characteristics and salinization processes of groundwater in the shallow aquifer of Eastern Laizhou Bay, China. Hydrological Processes 26:2322-2332. https://doi.org/10.1002/hyp.8362

Wu XC, Li CS, Sun B, Geng FQ, Gao S, Lv MH, Ma XY, Li H, Xing LT. (2020) Groundwater hydrogeochemical formation and evolution in a karst aquifer system affected by anthropogenic impacts. Environmental Geochemistry and Health 42:2609-2626. https://doi.org/10.1007/s10653-019-00450-z

Xie YC, Huang F, Yang H, Yu S. (2021) Role of anthropogenic sulfuric and nitric acids in carbonate weathering and associated carbon sink budget in a karst catchment (Guohua), southwestern China. Journal of Hydrology 599:126287. https://doi.org/10.1016/j.jhydrol.2021.126287

Yu L, Daniels LM, Mulders JJPA, Saldi GD, Harrison AL, Liu L, Oelkers EH. (2019) An experimental study of gypsum dissolution coupled to $\mathrm{CaCO}_{3}$ precipitation and its application to carbon storage. Chemical Geology 525:447-461. https://doi.org/10.1016/j.chemgeo.2019.08.005

Yu S, Du WY, Sun PA, He SY, Kuo YM, Yuan YQ, Huang J. (2015) Study on the hydrochemistry character and carbon sink in the middle and upper reaches of the Xijiang River Basin, China. Environmental Earth Sciences 74:997-1005. https://doi.org/10.1007/s12665-014-3771-y

Yu ZL, Wu GJ, Laura K, Li F, Yan N, Qu DM, Liu XM. (2019) Seasonal variation of chemical weathering and its controlling factors in two alpine catchments, Nam Co basin, central Tibetan Plateau. Journal of Hydrology 576:381-395. https://doi.org/10.1016/j.jhydrol.2019.06.042 
Zhang LL, Zhao ZQ, Zhang W, Tao ZH, Huang L, Yang JX, Wu QX, Liu CQ. (2016) Characteristics of water chemistry and its indication of chemical weathering in Jinshajiang, Lancangjiang and Nujiang drainage basins. Environmental Earth Sciences 75:506. https://doi.org/10.1007/s12665-015-5115-y

Zhang X, Xu ZF, Liu WJ, Moon S, Zhao T, Zhou XD, Zhang JY, Wu Y, Jiang H, Zhou L. (2019) Hydrogeochemical and Sr isotope characteristics of the Yalong River Basin, Eastern Tibetan Plateau: Implications for chemical weathering and controlling factors. Geochemistry, Geophysics, Geosystems 20:1221-1239. https://doi.org/10.1029/2018GC007769

Zhong YS, Wang LC, Xu Y, Zhang YM, Liu CL. (2020) Microfacies and multi-isotope records of Anisian sequences from the Upper Yangtze Block: possible responses to tectonics and climate-driven relative sealevel change. International Journal of Earth Sciences 109:489-509. https://doi.org/10.1007/s00531-02001817-9

\section{Figures}

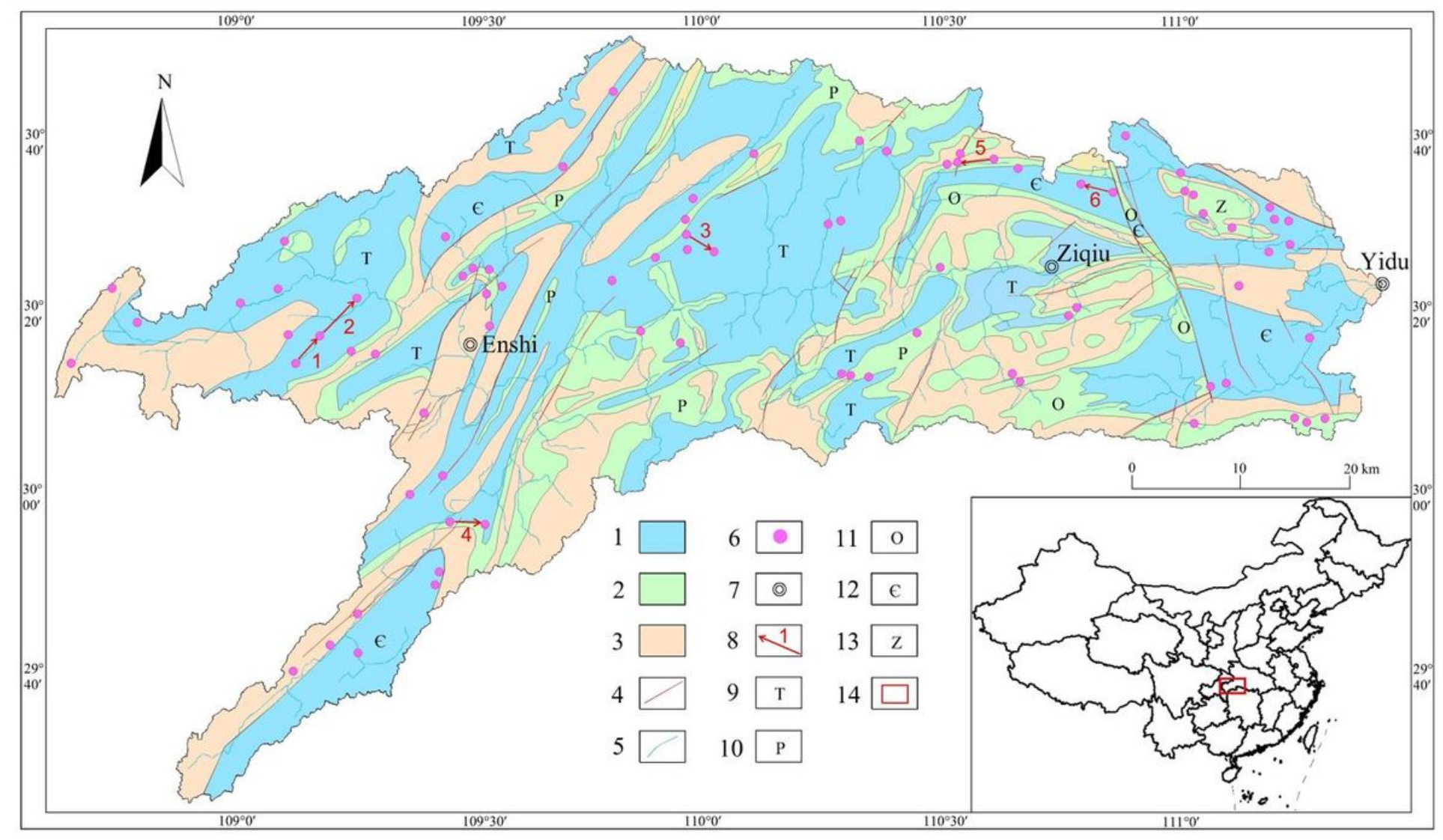

\section{Figure 1}

Hydrogeology map and sampling location in the study area. 1 Carbonate rock and evaporite, 2 Carbonate rock, 3 Sandstone and shale, 4 Fault, 5 Surface River, 6 Groundwater sample, 7 Town, 8 Flow path, 9 
Triassic formations, 10 Permian formations, 11 Ordovician formations, 12 Cambrian formations, 13 Sinian formations, 14 Study area

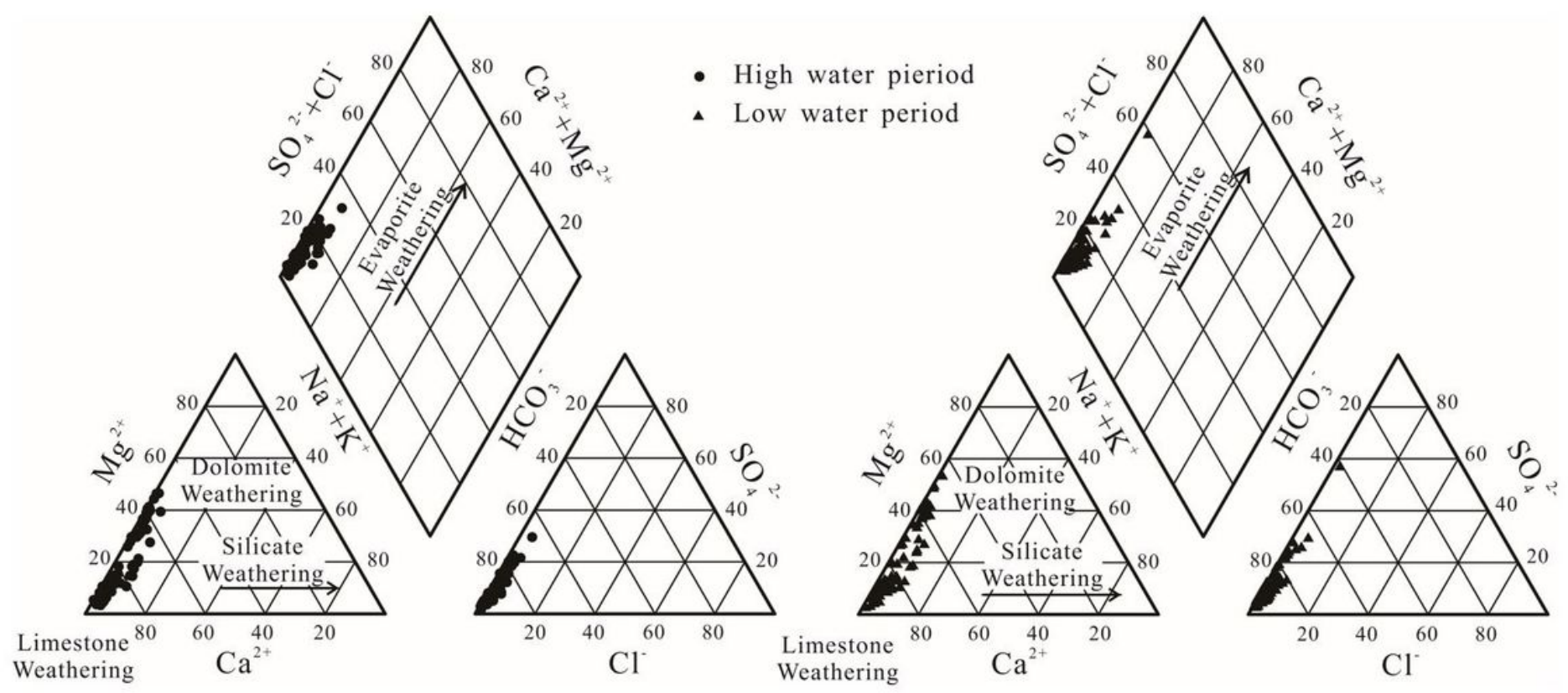

Figure 2

Piper diagram of the groundwater in Qingjiang river catchment


Figure 3

Plots of $[\mathrm{Ca} 2++\mathrm{Mg} 2+] /[\mathrm{HCO} 3-+\mathrm{SO} 42](\mathrm{a}),[\mathrm{Ca} 2++\mathrm{Mg} 2+] /[\mathrm{HCO} 3]$ (b) ratios for groundwater in Qingjiang catchment 


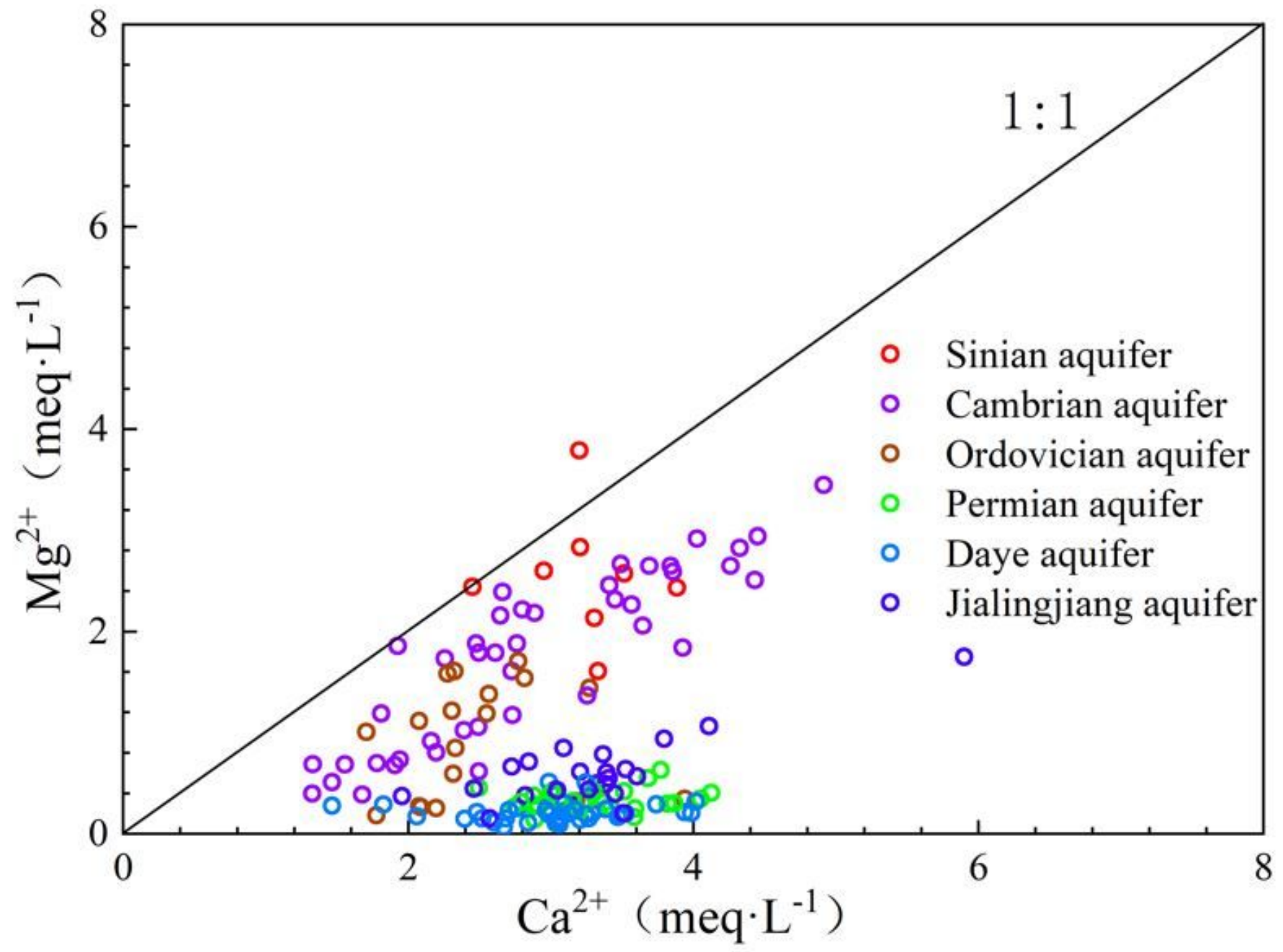

Figure 4

Plots of $[\mathrm{Ca} 2+] /[\mathrm{Mg} 2+]$ ratio for groundwater in different aquifers
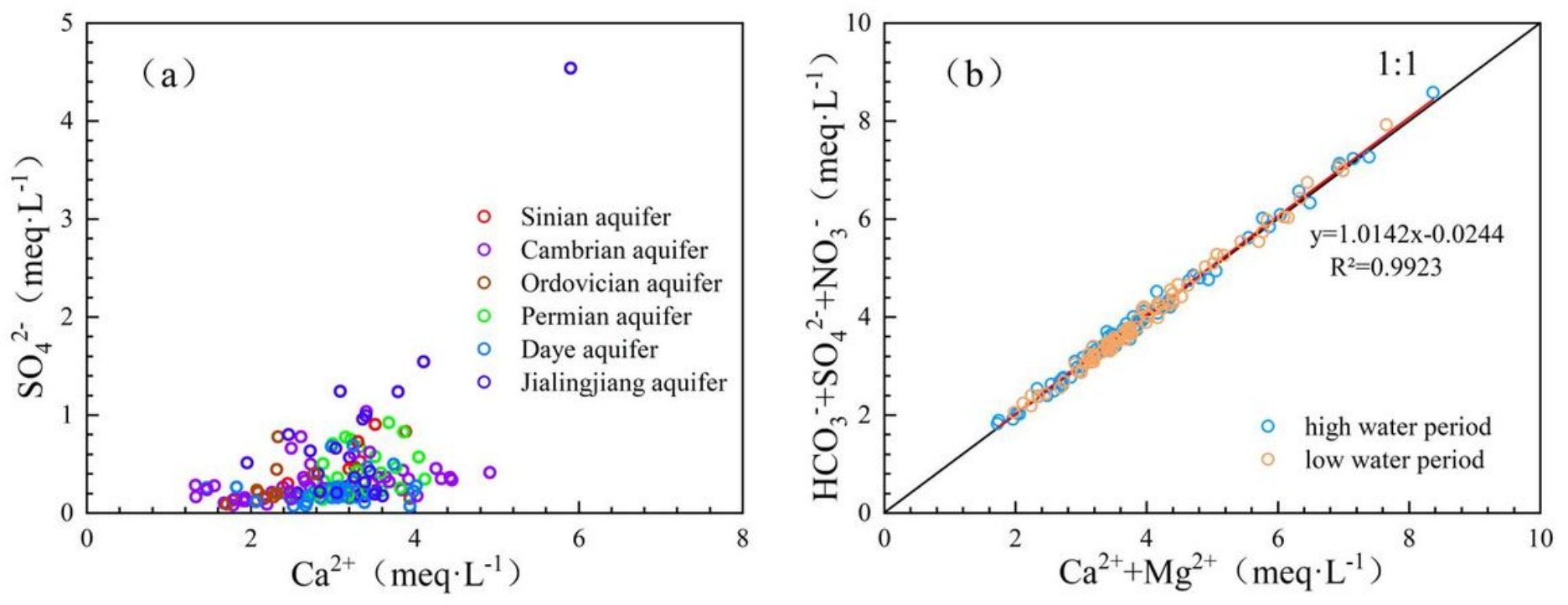
Figure 5

Plots of [Ca2+]/[SO42] (a), [Ca2++Mg2+]/[HCO3-+SO42-+NO3-] (b) ratios for groundwater
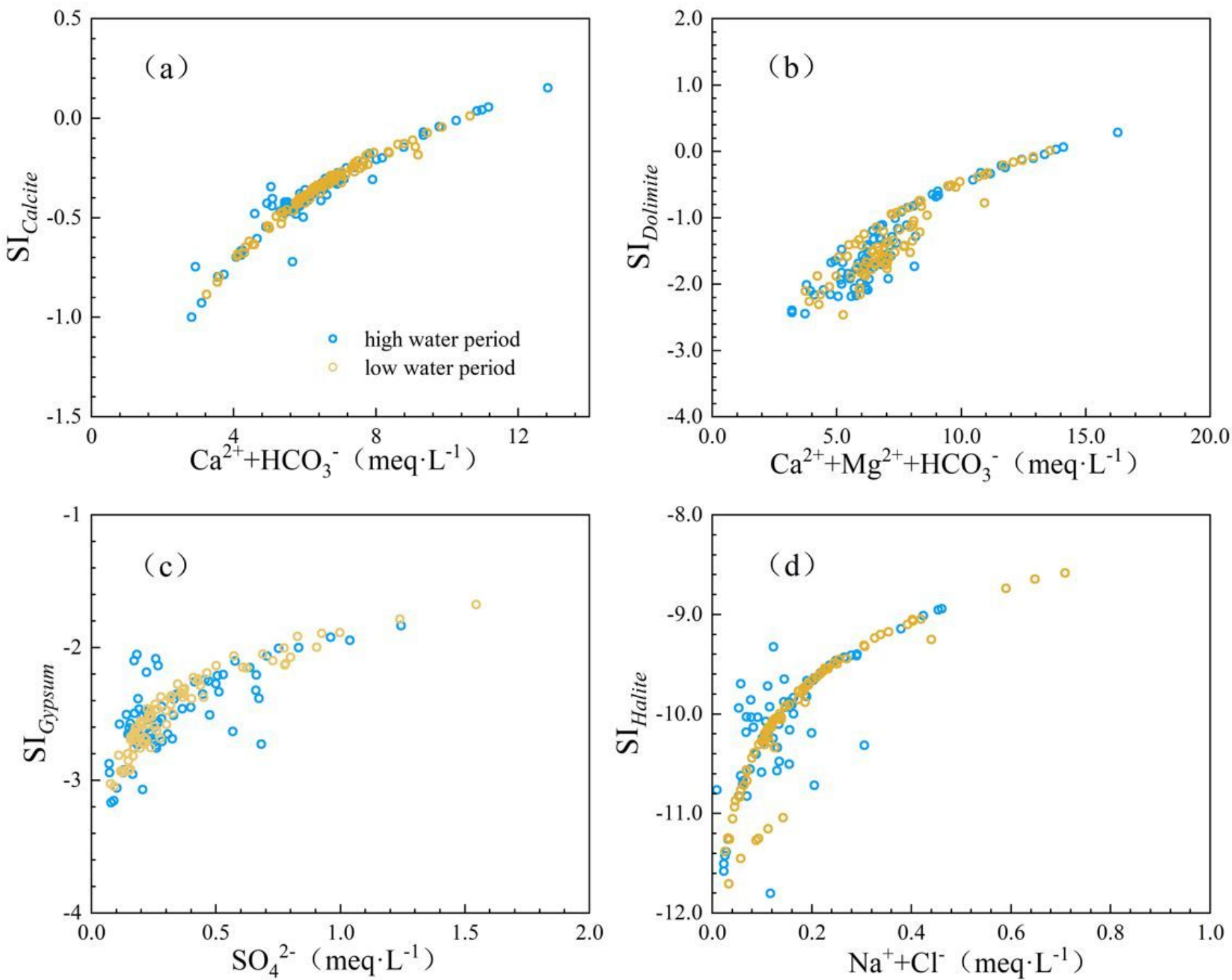

\section{Figure 6}

Plots of [Ca2++HCO3-]/SIcalcite (a), [Ca2++Mg2++HCO3-]/SIDolomite (b), [SO42-]/SIGypsum (c), $[\mathrm{Na}+\mathrm{Cl}-] /$ SIHalite $(d)$ ratios for groundwater 


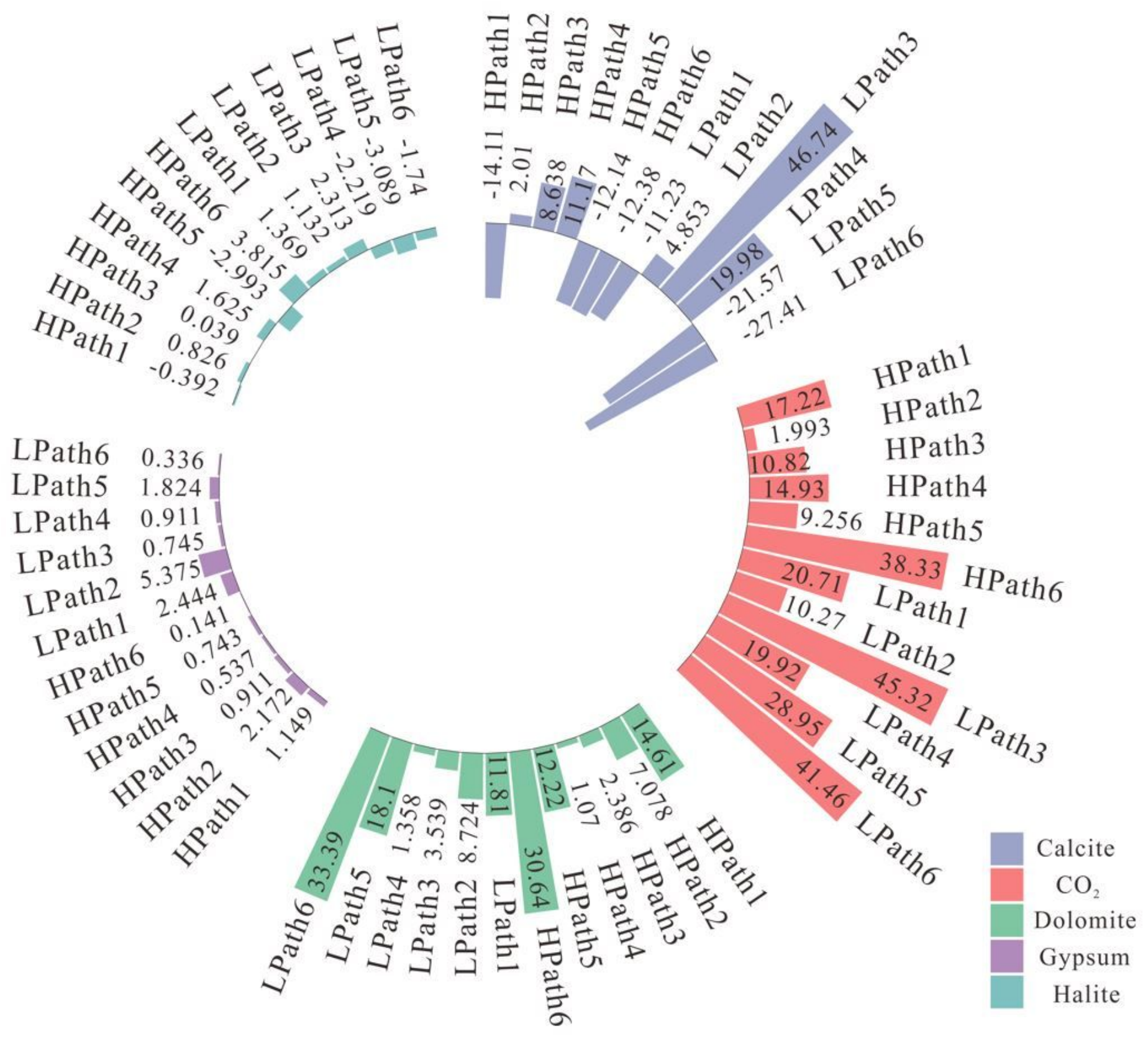

Figure 7

Inverse geochemical modeling results of groundwater along flow path (unit is $10 *-5 \mathrm{~mol} \cdot \mathrm{L}-1$ ). A positive number indicates that the mineral is dissolved, and a negative number indicates that the mineral is precipitated. 

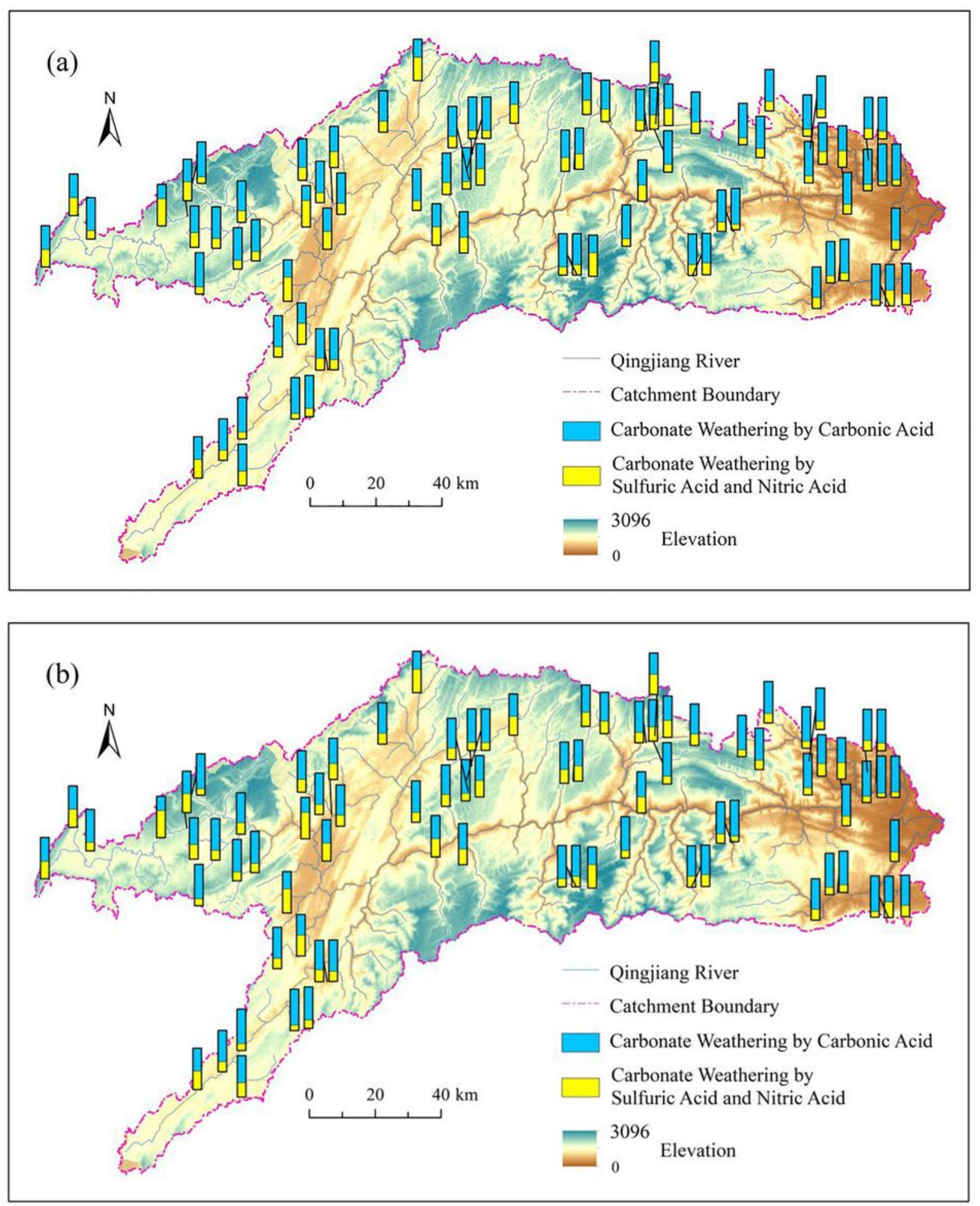

\section{Figure 8}

The contribution of carbonic acid, sulfate acid and nitric acid to carbonate weathering in high water period (a) and low water period (b) 


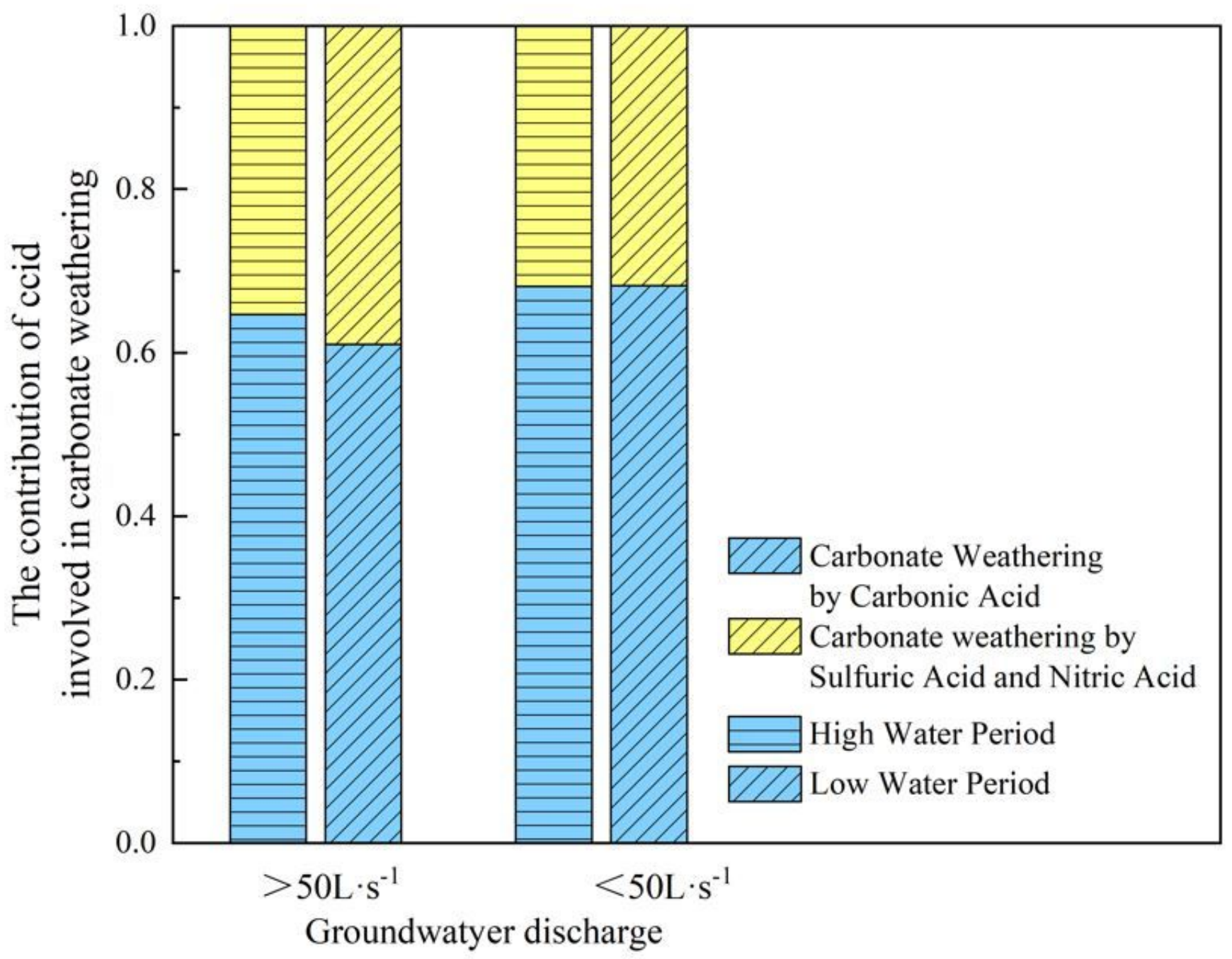

Figure 9

The relationship between groundwater discharge and carbonate weathering in different seasons 